\title{
ERGONOMIC WORK ENVIRONMENTAL MANAGEMENT FOR INFORMAL SECTOR WORKERS (CRAFTSMEN EMPING AND CRIPPERS) IN CILEGON CITY
}

\author{
Silvi Ariyanti ${ }^{1 *}$, Antonius Manurung ${ }^{2}$, Muhammad Kholil ${ }^{1}$, Yuliani Mardikawati ${ }^{1}$, \\ Prima Intania ${ }^{1}$ \\ ${ }^{1}$ Industrial Engineering Department, Mercu Buana University, \\ ${ }^{2}$ Psychology Department, Universitas Mercu Buana \\ *ariyantisilvi41@gmail.com
}

\begin{abstract}
Informal Sector Worker (Craftsman Emping And Crippers) In Cilegon City has many power. This deficiency can be seen in the condition of the workplace is very unhealthy and at risk for work accidents. Can be seen from the position of the workers who bend over, without using gloves when peeling, and the furnace furnace is not ergonomic for the workers when using it. According Nurmianto (2005), work fatigue will reduce performance and increase the level of work errors. Increased work errors will provide opportunities for workplace accidents in the industry. Static muscle loading (static muscular loading) if maintained for long periods will result in RSI (Repetition StrainInjuries), ie muscle, bone, tendon, and other pain caused by repetitive types of work. Therefore we provide solutions to conduct lectures on craftsman chips and chips in the city of Cilegon. On May 24, 2016 housed Mr. Rohim who is one of the successful craftsmen chips in the city of Cilegon.
\end{abstract}

Keywords: informal sector worker, RSI, lectures

\section{INTRODUCTION}

This accompaniment is done to meet the needs of assisted subjects, which arise because of the problems and challenges faced at this time, as well as the demands of quality improvement and work productivity in the future. One strategy to address the problems and challenges and efforts to meet these demands is to provide psychosocial assistance and ergonomic work environment management for informal sector workers, especially craftsmen and chips. Therefore, an initial approach is needed as a basic understanding map by conducting a "SWOT" analysis.

In general, questions arise to help understand the SWOT maps of informal sector workers and their working environment. Questions to ask are: 1) what are the factors that are the strengths and weaknesses of informal sector workers (craftsmen and chips). especially in Cilegon City ?; 2) what are the factors of opportunity and threat? and 3) what are the factors that can be used to improve the quality and productivity of informal sector work?

Based on preliminary observation and discussion, the identification and formulation of the main problem in this program is "how to develop psychosocial facilitation approach and ergonomic work environment governance for informal sector workers: craftsmen of chips and chips in Cilegon City".

In general the objective of the program is to develop a more complete and comprehensive understanding for assisted subjects to understanding the governance of ergonomic work environment in informal industry, especially craftsmen of chips and chips, as well as to awaken the subject of assistance to be willing to assist other informal sector workers in the management of the ergonomic work environment as an effort to further humanize other worker.

\section{LITERATURE REVIEW}


The focus of attention for assisting the governance of ergonomic work environment for the craftsmen of chips and chips is basically to prepare, to give, to develop, and to promote the assisted program in the effort to overcome the various complexity of health problems of work and ergonomics experienced by assisted subject.

Before provide support for assisted subjects, it should first be a personal, group, and community assessment. The results of the assessment conducted by the team will greatly assist in preparing mentoring programs and form the basis for developing a theoretical understanding of psychological and ergonomic impacts due to the complexity of the problems facing workers and the development of intervention models.

Preventative efforts prior to the emergence of psychological and ergonomic problems are furthermore important and urgent for the subject of assistance, so as to prevent things that cause greater effect. Of course, the subjects of assistance need to understand the immediate handling after the event can reduce the negative impact of the problem. One of the consequences of non-ergonomic working conditions and environments: hot temperatures, insufficient lighting, work tools and non-ergonomic working methods is the occurrence of work fatigue.

Fatigue shows different circumstances, but it all results in a reduction in work capacity and endurance (Suma'mur, 1996). Fatigue is a subjective feeling. The term fatigue leads to a condition of weakening the energy to perform an activity (Budiono, et al., 2003). Work-related fatigue is often defined as the process of decreasing efficiency, work performance and decreasing the physical strength or endurance to continue the activities to be performed (Wignjosoebroto, 2003).

According Nurmianto (2005), work fatigue will reduce performance and increase the level of work errors. Increased work errors will provide opportunities for workplace accidents in the industry. Static muscle loading (static muscular loading) if maintained for long periods will result in RSI (Repetition StrainInjuries), ie muscle, bone, tendon, and other pain caused by repetitive types of work.

\section{METHOD}

\section{Expected Target}

The expected targets in these mentoring activities, particularly for assisted subjects, and generally for MSME and UKK Post are to develop awareness of the importance of working health of craftsmen and chips, and to increase the knowledge, skills, abilities, as well as positive attitudes and behaviors of the assisted subjects in developing ergonomic work environment governance for informal sector industries, especially craftsmen emping and kripik

\section{Troubleshooting Framework}

Psychosocial support (occupational health psychology) and ergonomic work management (ergonomic) governance for assisted subjects are intended to equip workers to improve their psychological well-being so that they can stay optimally functioning in the face of various psychological and ergonomic problems in the workplace.

In psychosocial interventions (occupational health psychology) and ergonomic work environment governance should be of primary, urgent, and important concern. Thus intervention in complex problem-solving efforts needs to be done in the right way through the same perception and understanding of the standards and principles applied to the assisted subject.

The problem-solving framework to provide a reference for all interested parties in this activity, consisting of identify and formulate problems, conduct comprehensive and in-depth assessments, develop creative alternative solutions based on priority scale, execute problem solving, monitoring and evaluation of the program, and provide feedback.

\section{RESULTS AND DISCUSSION}




\section{Initial Condition of Emping Industry}

Based on the initial survey that has been done on the production area of the partners the drawback is the condition of the work location is very unhealthy and at risk of work accident as shown in Figure 1 below.

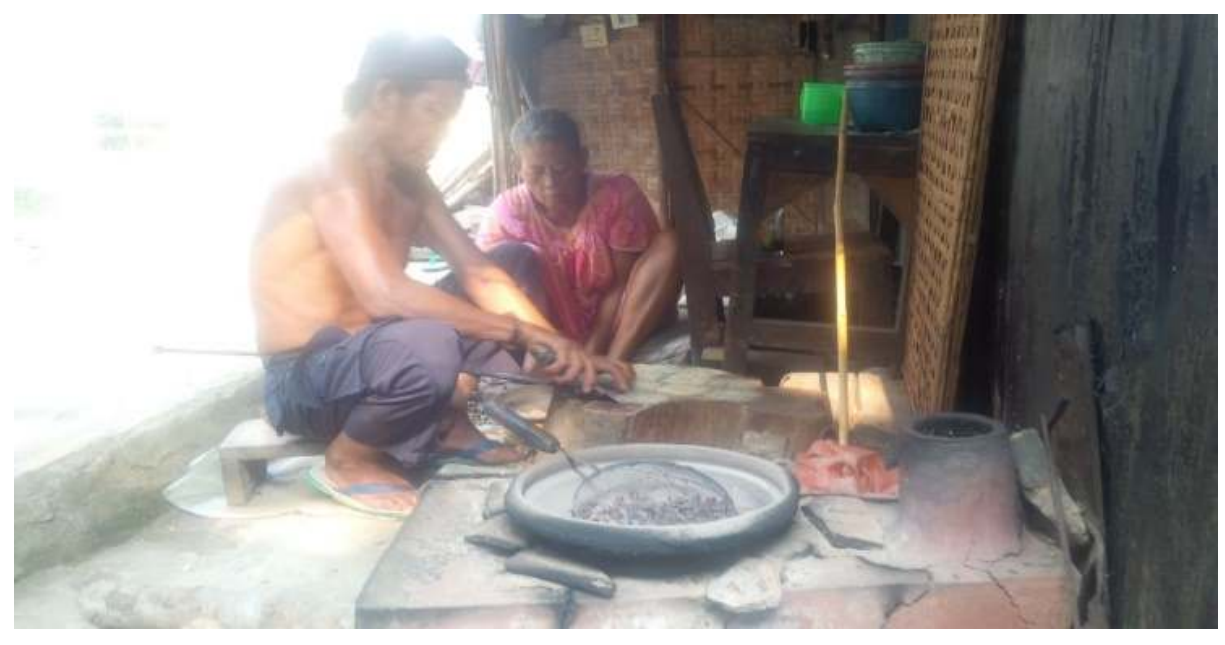

Figure 1. Workspace Conditions and Working Attitudes of Partners

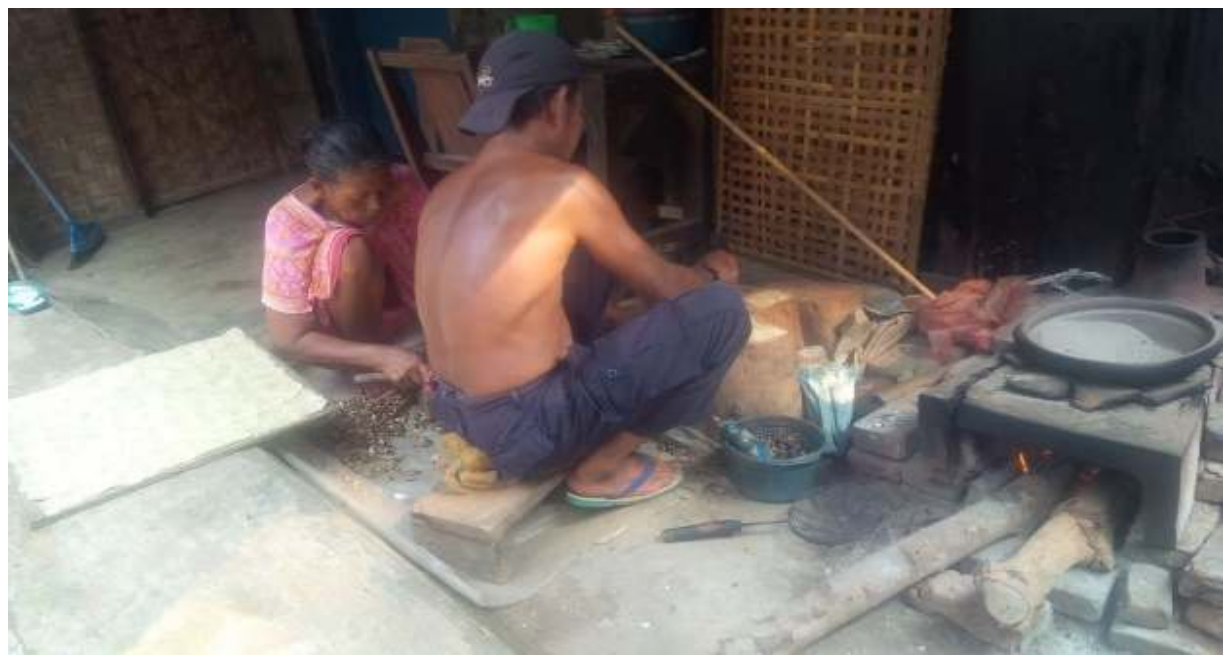

Figure 2. Workers Sitting Very Close to Furnace Burning in Time Hours.

In Figure 1 above it can be seen that the worker sat in a working position bending for hours. On the right side of the worker can be seen a burning furnace used for roasting Melinjo beans. This furnace needs to be close together because the roasted Melinjo, in hot conditions, must immediately peel the shell and be crushed immediately, as shown in figure 2 . The smoke produced from burning firewood is inhaled by workers for hours. This can cause shortness of breath / respiratory disorders in workers.

The process of stripping shells from Melinjo seeds and piping melinjo seeds is done without using gloves. This is very susceptible to injuries caused by being hit by a hammer and punctured by a Melinjo shell, as shown in Figure 3 and 4 below. From interviews conducted by the proposer team to a number of chips craftsmen, it turns out that so far they have often suffered hand injuries, whether due to a relatively hard hard pierced shell or hammer blow. 


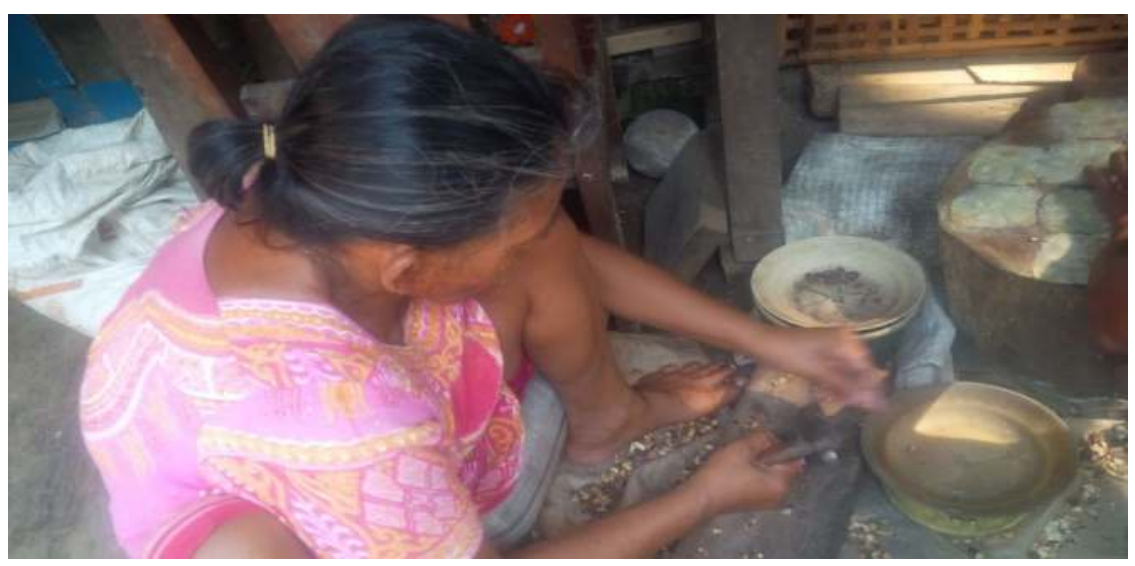

Figure 3. Shell Processing with Seed Melinjo

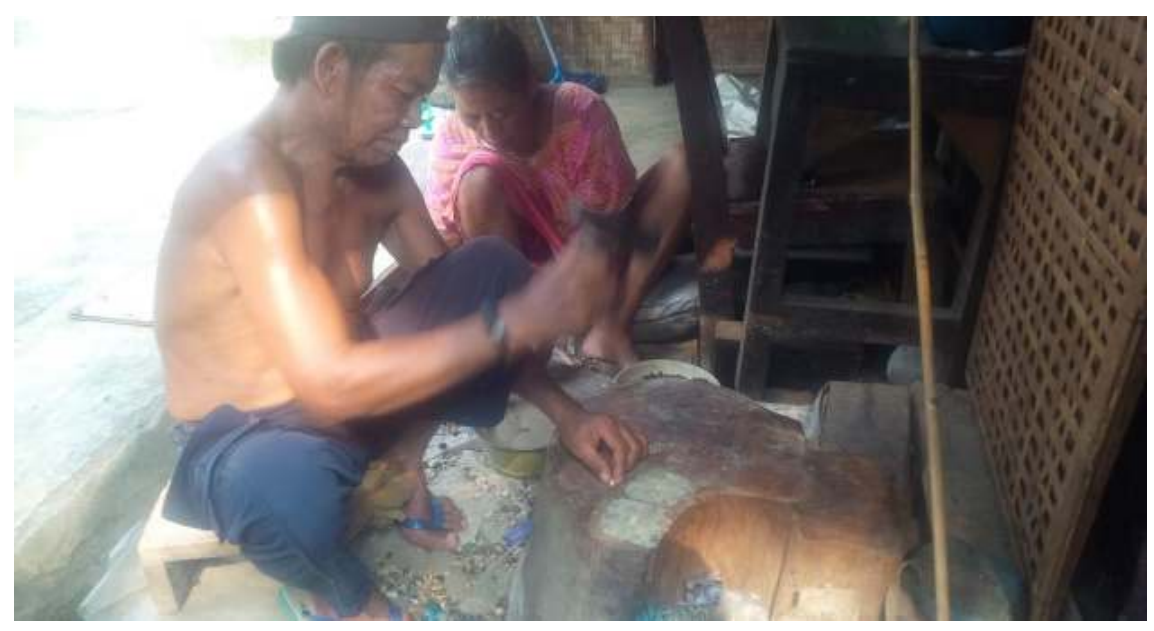

Figure 4. Melinjo Decrease Proces

\section{Initial Condition of Chips Industry}

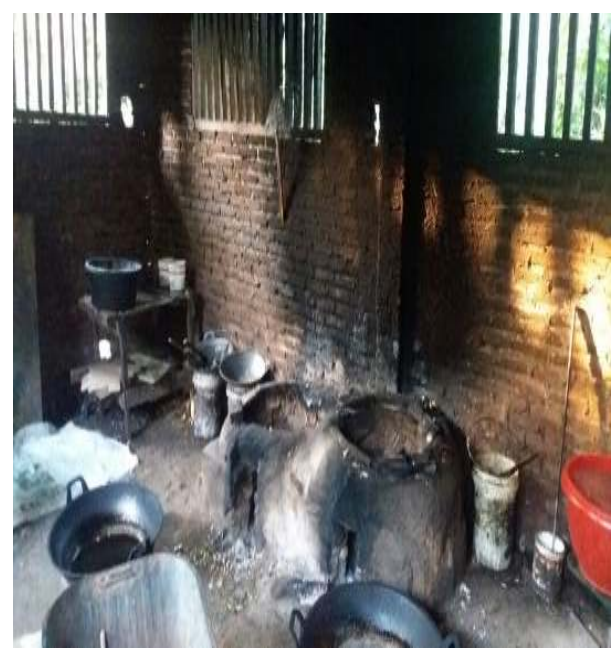

Figure 5. Kitchen Frying Chips

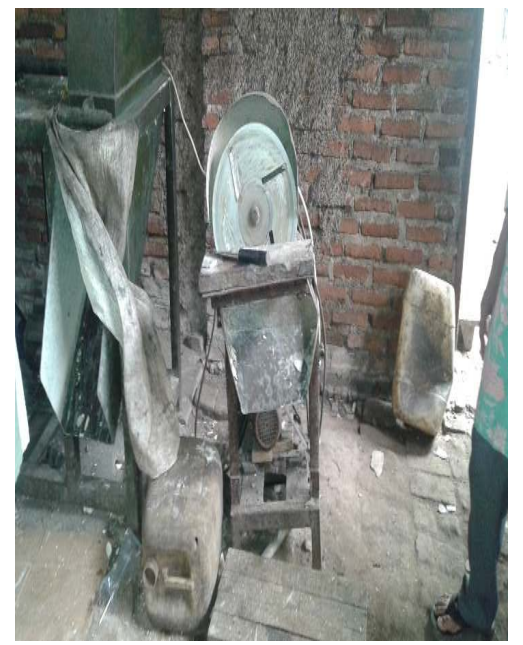

Figure 6. Condition of Sliced Raw Material for Chips 
From Figure 5 it can be seen that the partner kitchen is very dirty. Frying pan chips are not ergonomic because workers will bend. This condition will cause pain in the hips, neck, waist, new and legs of workers. Fatigue will lead to a lack of productivity from workers due to perceived pain.

From Figure 6 it can be seen that the working conditions of the filtration work are rather dirty and the machines used to slice are less secure because there is no rotary blade covering which can not protect the worker's hands from being hit by a rotating knife.

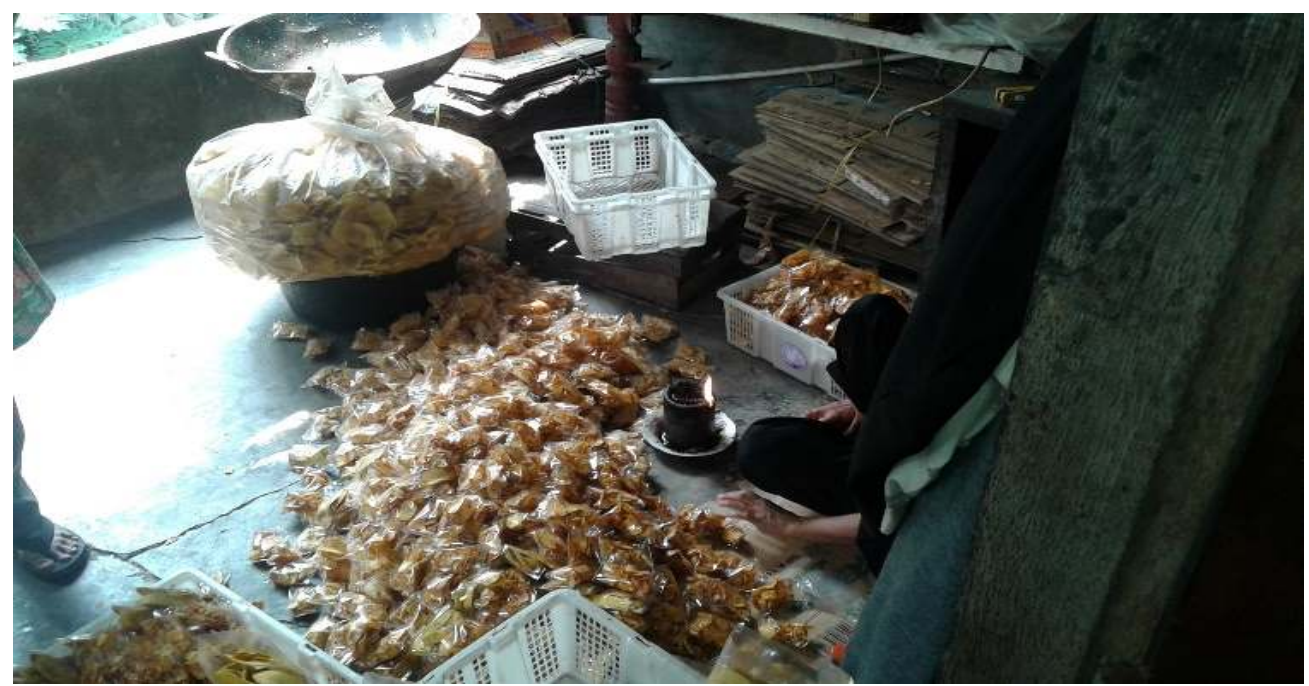

Figure 7. Area of Packing Chips Activities

From Figure 7 can be seen packing activities are still done traditionally by using candles to cover the plastic wrap. Activities carried out on the floor with packing conditions workers will bend over to the lighted candle. This will cause fatigue in the waist, neck, shoulders, and backs of workers who will cause pain in that section.

After accompaniment to craftsmen and chips crackers in the city of Cilegon the emping craftsmen have started wearing masks to protect their respiration from the smoke that arises from penyangraian seeds Melinjo. And also have used benches and tables from logs to do merlinjo slaughter.

\section{CONCLUSION}

Ergonomic work environment governance is an industry demand for more humanize human worker to work more secure, comfortable, and healthy life. From the results of preliminary observations conducted by the counterpart team is known a number of potential exposure and risk factors in craftsmen and chips workers.

The working environment of craftsmen and chips craftsmen in the city of Cilegon is not healthy very dangerous for workers' health. The posture of the worker in conducting the ergonomic production process activities is very dangerous to the worker. For that has been done assistance to awaken and provide understanding to the craftsmen the importance of a healthy work environment and ergonomic. After accompanied by assistance there has been a change in the emperor pengmerajin especially in the process of emping emping.

After training activities as a form of community service, the target audience has built stronger new commitments for MSME and UKK Post to develop strategic plan and operational plan in order to develop ergonomic work environment for craftsmen and chips. And for the continuing program it should be a programme due to development training for trainers for special escort teams with the formation of a team of companions from the subject of assistance who have volunteer identity professionally to help UMKM and other UKK Post. 


\section{REFERENCES}

Baker, K. (2000). Occupational health recognizing and preventing work stress related disease injury. Fourth edition. Jakarta: PT Gramedia.

Budiono, S., Jusuf, \& Pusparini, A. (2003). Bunga rampai HIPERKES \& Kesehatan Kerja. Semarang: Badan Penerbit Universitas Diponegoro.

David, R.F. (2015). Strategic Management: A Competitive Advantage Approach, Concepts. New York: Prentice Hall

Taylor, E.S., Peplau, A.L. \& Sears, O.D. (2009). Social psychology.Los Angeles: Prentice Hall

Tim Mahasiswa Fakultas Kedokteran UKRIDA (2015). Plant Survey Pos Upaya Kesehatan Kerja (UKK). Pengrajin Emping dan Kripik.Kota Cilegon.

Suma'mur P. K. (1993). Keselamatan Kerja Dan Pencegahan Kecelakaan. Jakarta: Haji Masagung. (1996). Higene Perusahaan Dan Kesehatan Kerja. Jakarta : PT Gunung Agung

Wignjosoebroto, S. (2003). Ergonomi Studi Gerak Dan Waktu. Surabaya: Guna Widya 